International Journal of Public Health Excellence (IJPHE)

Vol. 1, No. 1, January 2022, pp. 52 55

Journal homepage: https://ejournal.ipinternasional.com/index.php/ijphe/

ISSN: 2809-9826, DOI: https://doi.org/10.55299/ijphe.v1i1.12

\title{
The Influence of Knowledge of Mother Who Have Baby 6-12 Months on Supplementary Feeding
}

\author{
Elvi Suryani $^{1}$, Maryam Latifah Harahap ${ }^{2}$, Nur Aliyah Rangkuti ${ }^{3}$, Novita Sari Batubara ${ }^{4}$, Rya Anastasya \\ Siregar ${ }^{5}$, Ratna Dewi Siregar 6 \\ ${ }^{1,2}$ Diploma 3 Study Program, Darmais Padangsidimpuan Midwifery Academy, Indonesia \\ ${ }^{3,4,5,6}$ Health faculty, Aufa Royhan University, Indonesia
}

\begin{abstract}
Article Info
Article history:

Received November 27, 2021

Revised December 15, 2021

Accepted January 10, 2022

\section{Corresponding Author:}

Elvi Suryani

Diploma 3 Study Program,

Darmais Padangsidimpuan

Midwifery Academy, Indonesia

Email:

elvisuryani141@gmail.com

ABSTRACT

Based on data from the Health Organization (WHO) in 2002 reported that $54 \%$ of deaths were caused directly or indirectly by undernutrition and malnutrition. IV pijorkoling, southeast Padangsidimpuan sub-district in 2022. This type of research is descriptive using a total sampling of 30 respondents. Collecting data using a questionnaire sheet, researched based on influence, age, education, occupation, parity and sources of information. The majority of respondents with less influence are 18 people $(60 \%)$, the majority are less than $20-40$ years old as many as 16 people $(53.34 \%)$, the majority have less influence have a high school education as many as 15 people $(50 \%)$, the majority have less influence are household workers as many as 14 people, (46.67\%), the majority of respondents with low influence received information from health workers as many as 18 people (60\%) and the majority with less influence based on parity of mothers who gave birth 3-4 times as many as 10 people $(33.33 \%)$. The majority of the influence of mothers who have babies 6-12 months regarding complementary feeding is still lacking, so it is hoped that mothers will increase their influence and increase awareness and follow the instructions of health workers.
\end{abstract}

\section{Keywords:}

The Influence of Mothers Having Babies 6-12, Providing Complementary Foods for Breastfeeding

This article is licensed under a Creative Commons AttributionShareAlike 4.0 International License.

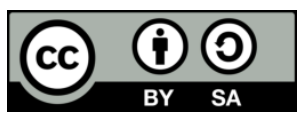

\section{INTRODUCTION}

Complementary foods for breastfeeding (MP-ASI) are introduced to babies, but breastfeeding should continue at least until the baby is 2 years old. At the age of 6 months, babies need to be introduced to complementary foods, namely complementary foods other than breast milk to meet the baby's increasing nutritional needs. Nutrition plays an important role in the human life cycle. Malnutrition in infants and children can cause growth and development disorders, if not treated early it can continue into adulthood. The age of 0-24 months is a period of rapid growth and development so that it is termed the "Golden Age" where at this time infants and children receive appropriate nutritional intake for optimal growth and development. Conversely, if infants and children at this time do not get food according to their nutritional needs, it will interfere with the growth and development of infants and children both now and in the future [19].

The World Health Organization (WHO) in 2002 reported that $54 \%$ of under-five deaths worldwide were caused directly or indirectly by malnutrition and malnutrition. This figure has not changed much in the $2011 \mathrm{WHO}$ data, which reported that $45 \%$ of under-five deaths worldwide were related to malnutrition. Furthermore, WHO data show that weight loss begins at the age of 4-6 months which is known as the weaning period. This is also reinforced by the finding that $2 / 3$ of the toddlers who died had the wrong baby diet, including not getting exclusive breast milk (ASI) and getting complementary foods (MP-ASI) that were too early or too late with the composition of nutrients. incomplete, unbalanced and unhygienic [3]. 
In developed countries a study conducted by Jane et.al in Perth, Australia, showed that $44 \%$ of infants had been given solid food before 17 weeks of age. Several other studies have shown that infants have been given solid food before the age of 4 months, namely $45 \%$ in New Zealand, 63\% in Finland, and $70 \%$ in Canada. Even from the results of a study in Scotland showed that $40 \%$ of infants have been given solid food at the age of 12 weeks. Early complementary feeding to infants $<6$ months of age should not be done because if solid food has been started before the baby's digestive system is ready to accept it, then the food will be eaten. They are not digested properly and can cause unpleasant reactions (indigestion, gas, and constipation). The number of increases in the provision of early MP-ASI does not only occur in developed countries, but also occurs in developing countries [10]-[12]

In developing countries, the European Society for Pediatric Gastrohepatology and Nutrition (ESPGHAN) recommends that complementary foods be introduced between 17 weeks - 26 weeks of age, but not later than 27 weeks. Prior to 2001, WHO recommended exclusive breastfeeding until the age of 4 months. The problem with complementary feeding in developing countries is the poor quality of food and poor hygiene, causing failure to thrive during the complementary feeding period. 45,46 The WHO systematic in 2002 which aimed to evaluate whether there were different results between infants with exclusive breastfeeding for 4 months versus 6 months stated that there were no studies showing that infants who were exclusively breastfed for 6 months experienced decreased growth in terms of weight. body length and body length so that WHO recommends exclusive breastfeeding until the age of 6 months and MP-ASI starting at the age of 6 months. MP-ASI given before the age of 4 months is classified as early MP-ASI, whereas if it is given after the age of 6 months it is classified as late MPASI [5]

Based on the results of the National Socio-Economic Survey (Susenas) in 2012, there are many mothers who give food too early to their babies, then as many as $32 \%$ of mothers give additional food to babies aged 2-3 months, and 69\% to babies aged 4-5 months. Based on the Indonesian Demographic and Health Survey (IDHS) in 2011-2012, about $40 \%$ of infants aged $<2$ months have been given complementary feeding. It was also stated that infants aged 0-2 months were given liquid complementary foods (21-25\%), soft/soft foods (20.1\%), and solid foods (13.7\%). For infants aged 3-5 months who were started to be given complementary foods, liquid (60.2\%), mashed/soft $(66.25 \%)$ and solid (45.5\%). Feeding that is too early and inappropriate causes many babies to suffer from malnutrition [2].

Giving MP-ASI is prioritized for infants from poor families to reduce the prevalence of protein energy deficiency (PEM). The percentage of infants receiving complementary feeding tends to increase from 2006-2009, from $34.44 \%$ (2006) to $73.5 \%$ (2009); but since 2010 it has decreased to $68.01 \%$, in 2011 to $26.98 \%$ and in 2012 only $23.31 \%$. This illustrates that the availability of MP-ASI has not been able to cover all infants who have malnutrition problems [4]

Based on a preliminary survey conducted by researchers on September 25, 2019 in Pal-IV Pijorkoling Village, Southeast Padangsidimpuan District, the author met with 8 mothers who had babies in Pal-IV Pijorkoling Village, saying that mothers did not know about complementary foods and only 2 mothers who know and have heard of complementary foods from health workers. In addition, there are 4 mothers who give complementary foods to breast milk for babies aged less than 4 months on the grounds that babies often cry and are fussy and feel hungry because it is not enough to only give breast milk so mothers give complementary foods. The types of complementary foods provided include cereals, milk porridge, team rice, and formula milk.

In connection with these matters, the researcher was interested in taking the title "The Influence of Mothers Who Have Babies 6-12 Months About Providing Complementary Breastfeeding Foods in Pal-IV Pijorkoling Village, Southeast Padangsidimpuan District in 2022".

\section{METHOD}

The research design used is a research using a total sampling technique, namely by making all mothers have babies who are in Pal-IV Pijorkoling Village, Southeast Padangsidimpuan District in 2022 as a research sample, which is as many as 30 people. This research begins with the submission of the title and the initial survey until the scheduled or planned time in August 2022. The population in this study amounted to 30 people. The sample in this study amounted to 30 samples. The data used are primary data and secondary data. The data were analyzed by multiple logistic regression [18].

\section{RESULTS AND DISCUSSION}

The influence of respondents regarding complementary feeding according to age is the majority with less influence with the age of 20-40 years, namely 16 respondents $(53.34 \%)$ and the minority having sufficient influence, namely 8 respondents $(26.66 \%)$. Age $<20$ years is the majority with sufficient influence, namely 2 respondents $(6.67 \%)$ and minority with less influence as much as 1 person $(3.33 \%)$ and age $>40$ years is the majority with sufficient influence, namely 2 respondents (6.67\%) and minority have less influence as much as 1 person (3.33\%).

The gender of the respondents is female, namely breastfeeding mothers in Pijorkoling Village, Padangsidimpuan District. Parity of respondents Based on the results of the study, it was found that the influence of 
respondents regarding complementary feeding according to parity was that the majority had sufficient influence with primiparous parity, namely 3 respondents $(10 \%)$ and the minority was less than 3 people (10\%). the majority is sufficient based on scundipara parity as many as 4 people (13.33\%) and the minority is less as much as 1 person (3.34\%). the majority is less based on multipara parity as many as 4 people $(13,33 \%)$.

The work of the respondents based on the results of the study showed that the influence of respondents on complementary feeding based on work was the majority had less influence with household work, namely 14 respondents (46.67\%) and the minority had sufficient influence as many as 9 people (30\%), the majority were quite based on self-employed work, namely 2 respondents $(6.67 \%)$ and a minority of less than 1 person (3.33\%), the majority of the influence is less based on the work of farm workers as many as 3 people (10\%) and the minority is sufficient as much as 1 person $(3.33 \%)$.

the majority have less influence as many as 18 respondents $(60 \%)$, the minority with moderate influence are 12 respondents $(40 \%)$ and there is no good influence $(0 \%)$. Based on the results of the study, it was found that the influence of respondents regarding the provision of complementary feeding based on information sources was that the majority had less influence by obtaining sources of information from health workers, namely 18 respondents $(60 \%)$ and the minority was sufficient as many as 6 respondents $(20 \%)$, the majority were sufficient based on information sources from health workers. electronic media as many as 6 respondents $(20 \%)$.

Based on the results of the study, it was found that the influence of respondents regarding the provision of complementary feeding based on education was the majority had less influence with high school education, namely 15 respondents $(50 \%)$, the minority was sufficient, namely 7 respondents $(23.34 \%)$ and the majority based on higher education, namely 4 respondents. $(13.33 \%)$ the minority is sufficient and the majority is less based on junior high/equivalent education, namely 3 respondents (10\%) and the minority is sufficient, namely 1 respondent (3.33\%) and the majority is less based on elementary/equivalent education, namely none.

\section{CONCLUSION}

From the results of research on the influence of mothers who have babies 6-12 months of age regarding complementary feeding, the following conclusions were obtained, From the total 20 respondents, the majority had 18 people (60\%), the minority had sufficient influence, namely 12 people. (40\%) and no good influence $(0 \%)$. The influence of respondents based on age, the majority with less influence with age 20-40 years as many as 16 people $(53.34 \%)$, and minority respondents with less influence with age $<20$ years and age $>40$ years each as many as 1 person $(3.33 \%)$. The influence of respondents based on education, the majority had less influence with high school education as many as 15 people (50\%), and the minority of respondents had enough influence with junior high school education as many as 1 person $(3.33 \%)$. The influence of respondents based on occupation, the majority have less influence on household work as many as 14 people $(46,67 \%)$, while the minority of respondents have enough influence with farmer work as much as 1 person (3.33\%) and respondents with less influence with self-employed work as much as 1 person $(3,33 \%)$. The influence of respondents based on sources of information, the majority have less influence by getting information sources from health workers as many as 18 people (60\%), and the minority of respondents with sufficient influence to get sources of information from electronic media as many as 6 people (20\%). The influence of respondents based on parity, the majority of mothers gave birth 3-4 times as many as 10 people $(33.33 \%)$, and the minority of respondents had less influence with mothers who gave birth 2 times as many as 1 person $(3.33 \%)$

\section{ACKNOWLEDGEMENTS}

Author thanks Maryam Latifah Harahap, Nur Aliyah Rangkuti, Novita Sari Batubara, Rya Anastasya Siregar, Ratna Dewi Siregar. In most cases, sponsor and financial support.

\section{REFERENCES}

[1] Arikunto, Research Procedure, An Approach. Vol. 1, $1^{\text {st }}$ ed, Renika Cipta, Jakarta, Indonesia, 2006.

[2] Asih.,\& Risneni, Postpartum and Breastfeeding Midwifery Care. Vol. 2, $2^{\text {nd }}$ ed, Trans Info Medika, Jakarta, Indonesia, 2018

[3] Glassier.,\& Gebbie, family planning and reproductive health. Vol. 3, $4^{\text {th }}$ ed, Buku Kedokteran EGC, Jakarta, Indonesia, 2010.

[4] Manuaba, Obstetrics, Gynecology, and Family Planning. Vol. 2, 2 ${ }^{\text {nd }}$ ed, Buku Kedokteran EGC, Jakarta, Indonesia, 2010.

[5] Manuaba, Obstetrics, Gynecology, and Family Planning. Vol. 1, $1^{\text {st }}$ ed, Buku Kedokteran EGC, Jakarta, Indonesia, 2009.

[6] Machfoedz, Ircham, Research methodology. Vol. 4, $2^{\text {nd }}$ ed, Fitramaya, Yogyakarta, Indonesia, 2009.

[7] Mulyani.,\& Rinawati, Family Planning And Contraception, Vol. 1, $1^{\text {st }}$ ed, Nuha Medika, Yogyakarta, 2013

[8] Notoatmodjo.Soekidjo, Health Research Methodology. Vol, 2, 2nd ed, Rineka Cipta, Jakarta, Indonesia, 2010.

[9] Notoatmodjo.Soekidjo, Health Research Methodology. Vol. 1, 1st ed, Rineka Cipta, Jakarta, Indonesia, 2005

[10] Notoatmodjo.Soekidjo, Health Promotion Theory and Application, Vol. 3, 3rd ed, Rineka Cipta, Jakarta, Indonesia, 2010.

[11] Notoatmodjo.Soekidjo, Health Promotion Theory and Application, Vol. 2, 1st ed, Rineka Cipta, Jakarta, Indonesia, 2005.

[12] Notoatmodjo.Soekidjo, Health Education and Behavior. Vol. 1, 1st ed, Rineka Cipta, Jakarta, Indonesia, 2003.

[13] Novita, Health promotion in midwifery services. Vol. 1, 1st ed, Salemba Medika, Jakarta, Indonesia, 2011.

[14] Pinem, Reproductive health and contraception. Vol. 2, 1st ed, TIM, Jakarta, Indonesia, 2009.

[15] Saryono, Practical guiding health research methodology for beginners. Vol. 3, 1st ed, Mitra Cindikia, Yogyakarta, Indonesia, 2009. 
[16] Saiffudin, Practical Guide to Contraceptive Services. Vol. 1, 1st ed, Sarwono Prawirohardjo, Jakarta, Indonesia, 2003.

[17] Saiffudin, Practical Guide to Contraceptive Services. Vol. 2, 2nd ed, Sarwono Prawirohardjo, Jakarta, Indonesia, 2006

[18] Sugiyono, Educational Research Methods. Vol. 1, 1st ed, CV.Alfabeta, Bandung, Indonesia, 2009.

[19] Sulistyawati, Family Planning Services, Vol. 1, 4th ed, Salemba Medika, Yogyakarta, Indonesia, 2012.

[20] Marandi SA. "Journal of Tab and Tazkiya, "Nutrition with complementary foods. Research \& Scientific", Vol. 11, No. 3, pp 35-40, June 2001

[21] Weinstein ME, Oleske JM, Bodgden JD. “A selected review of breast - feeding recommendation”. Vol.26 No.8, pp 379-84, 2006.

[22] Gorstein J, AkreaJ. The use of anthropometry to assess nutritional status WID Health Stat Quart. Vol,4 No.1, pp 48-58, 1988.

[23] Kligman B, Behrman R, Jenson H. Review of Pediatrics. Philadelphia: W. B. Saunders Company, Vol. 4 No. 4, pp 344-60, 2000

[24] Neumann CG, Gewa C, Bwibo NO. Child nutrition in developing countries. Pediatr Ann.; Vol. 33 No. 10, pp 658-74. 2004

[25] Kahbazi M, Farahani A. Effect of Education on Knowledge and Attitude in infant complementary feed under 1 years. Research \& scientific journal of Arac. Rahavard danash, Vol.5 No. 2pp 19- 23. 1998. 